\title{
The Application of Accounting Methodology of Radar Charts to Analyze the Sector of Sawmilling and Planning of Wood of Austria.
}

\author{
Miguel Angel Pérez Benedito \\ miguel.a.perez@uv.es
}

\begin{abstract}
The accounting methodology of radar charts (AMRCh) explains the behavior of companies through average periods of maturation of management activity on short term. These variables represented on each one of axes of radar chart allow measure the activity of companies, applying the cosine and sine theorems of plane geometry. The analysis of activity is for each one of areas represented on a radar chart through by non-slanted indicators. This study shows that frontier effect carry out companies to adopt a sectorial management to maintain their activity. This manuscript presents the basic theory of AMRCh, firstly. Secondly, the study analyzes the management of industrial sector, which carries the research to the evaluation of the location of companies by the frontier effect. The manuscript concludes that a company adopts a management strategy according to trade conditions of industrial sector.
\end{abstract}

Keyboard. New methodology. Management behavior. Frontier effect. Location companies. Economic sociology.

\section{INTRODUCTION}

This study of the behavior of Manufacture of veneer sheets and wood based panels on Austria done by applying the accounting methodology of radar chart (AMRCh) explains the management results of sector companies on period from 2005 to 2013 as the main aim. In this financial crisis period, companies needs take changes to carry out their decisions to maintain a continued activity.

The tendency to obtain new indicators to justify the making decisions on both public and private sector, knows as New Management Public (Brusca, Montesinos, 2014. Kattel at al, 2014. Kuipers, et al, 2014) and the report of management of listed companies (IOSCO, 2003. IASB, 2010, SEC, 2010. CNMV, 2013) respectively, is a need to explain to stakeholder the situation of their investment or relation with sector public. At same time, the tools to measure the Strength, Weakness, Opportunity and Threat (SWOT) ever are present to evaluate the making decisions and to be applied on a singular sector or situations (Erliza et al, 2014. Prewitt \& Weil, 2014. Van Durme et al. 2014). Nevertheless, the subjective criteria to make indicators, the maintaining of validity of variables applied on indicators along of period and the justification of the applying of indicators based on the past literature obliges to review the explicative capacity of indicators of management.

The AMRCh methodology evaluates the behavior of company by criteria generated from general theories of cosine and sine of plan geometry. These geometric theories can be maintained ever and the economic and financial interpretation too. When a researcher see a radar chart not only is seeing a geometrical figure, the researcher is seeing too a management 
decision and these decisions should be measured and evaluated as well, to explain to the stakeholders the result of management.

The manuscript is divided into several units to explain changes of management on wood sector on Austria. The first unit of manuscript presents the principles of AMRCh. The second unit explains the transvers behavior of companies considering the situation of companies on periods selected. It explains the effect of financial crisis and shows how the sector does not have a same behavior. These differences led the research on companies management toward analyze the location of companies, and it explains why the frontier effect can change the management of companies. Nevertheless, the conditions of sector transactions have too an effect on changes of management, and this factor is an open issue for futures research lines. This issue can be discussed in other manuscripts, because the current aim of this manuscript is prove the explained capacity of AMRCh.

The conclusions are building along of manuscript and pursuit the explaining of behavior of sector companies through AMRCh. The AMRCh have flexibility to be applied according to needs of researchers, but this manuscript continues the research begun for Perez in others works previous to this, to prove and improve the application of a new methodology. The characteristics of its indicators and multidirectional effects of the decision making are factors which do of this methodology an alternative to measure the activity of companies.

\section{The Accounting Methodology of radar chat (AMRCh)}

The AMRCh consists on evaluation of company management from the angular coefficients of a radar chart. These angular coefficients are obtained by application of theorems of cosine and sine and their economic and financial interpretation is possible because averages period of maturation are on each axis of radar chart. The general expression (1), which is on an axis or radar chart, is as below.

$$
\begin{gathered}
p i * r i=t(365) \\
\mathrm{i}=\mathrm{c}(\text { collect), } \mathrm{p} \text { (payment), } \mathrm{s} \text { (sales) }
\end{gathered}
$$

The valuation of an axis on this methodology does not need any transformation, and the upper and lower limits of each axis are 365 and 1, respectively. It is need take on account those values of each axis have to be averages obtained from information of annual accounts, thus there will be a relation between the radar chart and the financial situation of company.

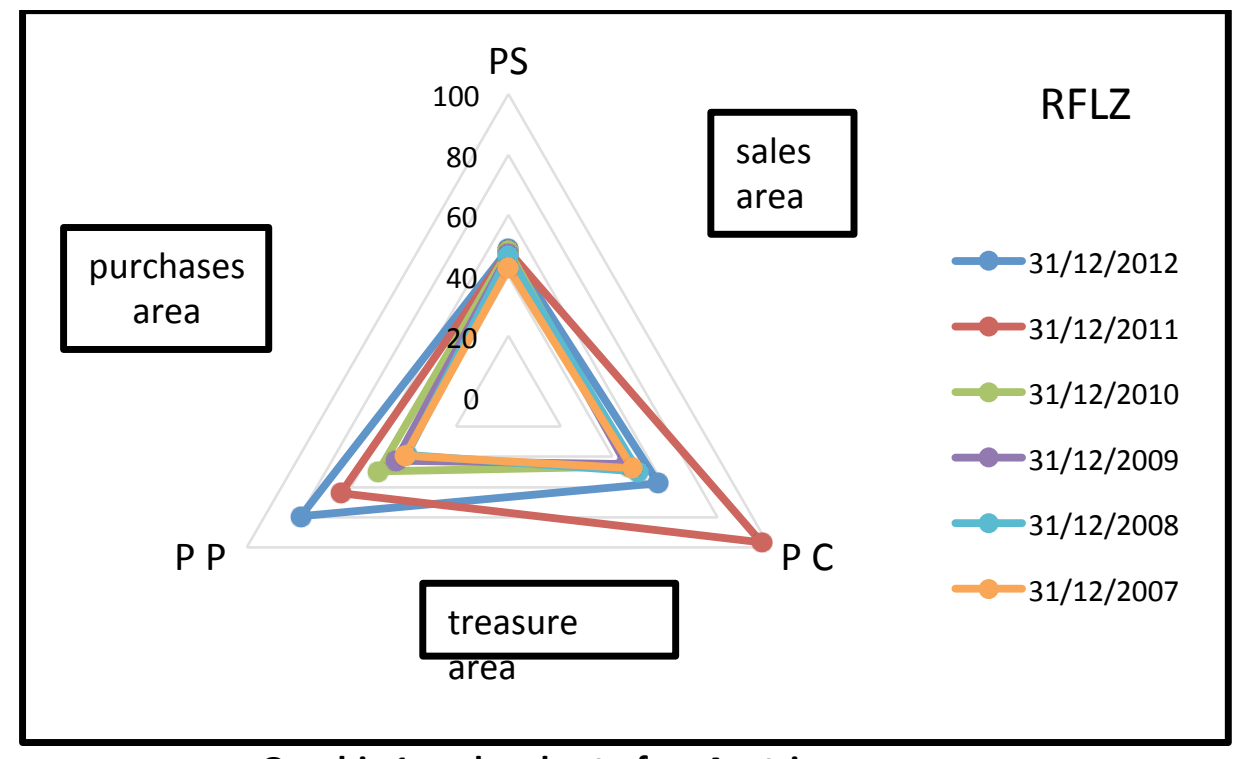

Graphic 1: radar chart of an Austrian company 
The graphic 1 are radar charts of a company of this study for each year. The behavior of company change along of period. These changes are measured by distances between axes of radar chart, from each average period of maturation, and they are obtained for application of cosine theorem, according to expression 2.

$$
\begin{gathered}
P D_{k}^{2}=p_{i}^{2}+p_{j}^{2}-2 \cos 120 * p_{i} * p_{j} \\
\mathrm{i} \neq \mathrm{j} ; \mathrm{i}=\mathrm{j}=1 \text { (sales), } 2 \text { (treasure); } 3 \text { (purchases) }
\end{gathered}
$$

The criteria applied to know the financial significance of perimetral distance on a year is monetary and named financial slack. A financial slack is a perturbation of perimetral distances (PDs) without repetition. When DP3 is more than DP1 the perimetral distance is positive and, on the contrary, when DP3•is less than that the distance DP1 is called negative. The kind of financial slacks obtained are 6 and their ranking are on table 1, applying a monetary criterion. When the perimetral distance of treasure (DP2) is greater of them, there is trust of financial market if the Financial Slacks are positive, and company can take external financing. On the contrary, when Financial Slacks are negative, the company gives credit to financial market to continue its activity.

Table 1 The Financial Slacks.

\begin{tabular}{|c|c|c|c|}
\hline \multicolumn{2}{|c|}{ Positive Financial Slacks (DP3>DP1) } & \multicolumn{2}{|c|}{ Negative Financial Slacks (DP3<DP1) } \\
\hline ( A ) & DP2>DP3>DP1 & ( D ) & DP1 $>$ DP3 $>$ DP2 \\
\hline ( B ) & DP3>DP2>DP1 & ( E ) & DP1 $>$ DP2 $>$ DP3 \\
\hline ( C ) & DP3>DP1>DP2 & (F ) & DP2 >DP1 $>$ DP3 \\
\hline
\end{tabular}

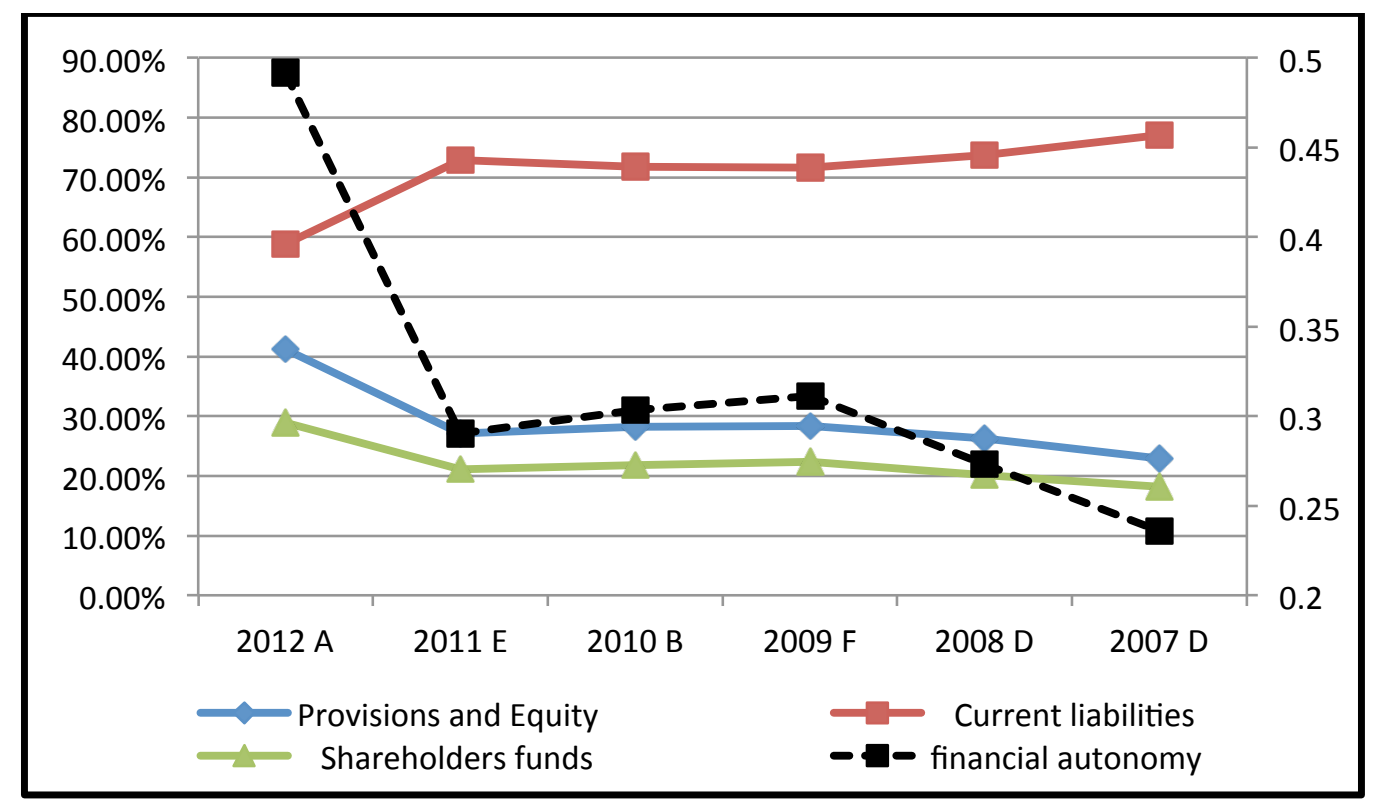

Graphic 2. The evolution of financial structure of company

The criteria applied to measure the activity of company according kind of financial slacks can be contrast with de evolution of liability accounts of balance sheet on graphic 2 . When financial slacks are negative, the ratio of financial autonomy increases, as years from 2007 to 2011 because company gives credit to market, increasing its Equity. The change of financial slack on 2012 supposes the financial market has trust of the company. On this year, the company changes the financial structure and the current liability is settled by increasing the Equity and Provisions.

To measure financial effect by this methodology, the application of sine theorem allows measure the orienteering or Perimetral Distances. So that, each financial slack will have its 
own criteria for measure the financial situation of company on sort term by its respective angular coefficients. The expression 3 is the sine theorem for each area in AMRCh.

$$
\frac{P D k}{\text { sine } 120}=\frac{p i}{\text { sine } \alpha k}=\frac{p j}{\text { sine } \beta k}(3)
$$

$\mathrm{I} \neq \mathrm{j} ; \mathrm{i}=\mathrm{j}=\mathrm{s}$ (sales), c (collect), $\mathrm{p}$ (payment)

$\mathrm{K}=1$ (sales area), 2 (treasure area), 3 (purchases area)

The comparing of perimetral distance on each financial slack two by two can allow the condition to measure the activity of company. This comparison generates several kinds of financial conditions, necessary and sufficiency conditions. The sufficiency conditions are on table 2 y 3 respect the financial slacks $B$ and $E$ of table 1, respectively.

\begin{tabular}{|c|c|c|}
\hline CS/LR & $\begin{array}{l}\text { EVALUATION OF AREAS } \\
\text { TO FIANCIAL SLACK (B) }\end{array}$ & $\begin{array}{l}\text { EVALUATION OF AREAS } \\
\text { TO FINANCIAL SLACK ( E) }\end{array}$ \\
\hline & AREA 1 & AREA 1 \\
\hline SC1 & $\alpha 2 / \beta 3>1$ & $\beta 3 / \alpha 2>1$ \\
\hline \multirow[t]{2}{*}{ LR1 } & $1>\beta 2 / \alpha 3>C V / V^{*}(1+V A T)$ & $\beta 2 / \alpha 3<\mathrm{CV} / \mathrm{V}^{*}(1+\mathrm{VAT})<1$ \\
\hline & AREA 2 & AREA 2 \\
\hline SC2 & $\beta 1 / \alpha 3>1$ & $\alpha 3 / \beta 1>1$ \\
\hline \multirow[t]{2}{*}{ LR2 } & $1>\alpha 1 / \beta 3>C^{*}(1+\mathrm{VAT}) / \mathrm{V}^{*}(1+\mathrm{VAT})$ & $\alpha 1 / \beta 3<\mathrm{C}^{*}(1+\mathrm{VAT}) / \mathrm{V}^{*}(1+\mathrm{VAT})<1$ \\
\hline & AREA 3 & AREA 3 \\
\hline SC3 & $\alpha 1 / \beta 2>1$ & $\beta 2 / \alpha 1>1$ \\
\hline LR3 & $1>\beta 1 / \alpha 2>C^{*}(1+\mathrm{VAT}) / \mathrm{CV}$ & $\beta 1 / \alpha 2<\mathrm{C}^{*}(1+\mathrm{VAT}) / \mathrm{CV}<1$ \\
\hline
\end{tabular}

The sufficiency conditions ( $\mathrm{SCi}$ ) of table 2 measure the capacity of activity on an area to get a financial position according to benefit the interest of company, and the conditions of liquidity result (LRi) measures the relation between a financial position and the result of management on an area. When this relation it is fulfilled, the company knows that this area have not necessities of an external financing of it, and it allows saying that it is an optimal position on this area in AMRCh methodology.

The indexes of angular coefficients on an area are different to the indexes of area on table 2. This situation proves the character multidirectional of making decisions. So that, a change on average period of payment has its effect on financial situation of sales area, because this movement changes perimetral distances 2 and 3, at same time both, and also their angular coefficients. That to say, the capacity to collect the client credit before to the sale of goods is measured from average period of payment by perimetral distance PD2 and PD3, and through two kinds of financial significance, SC1 and LR1. It allows knowing what the nature of management risk is.

The singular analysis of management of radar chart on graphic 1 is made by indicators of angular coefficients and their behaviors are on graphic 3 and 4. It allows seeing a change of tendency of financial autonomy on 2009 year on graphic 3. So that, from 2007 to 2009, its tendency is according to the indicator of financial sufficiency of sales area (RSF1). Its change on 2010 goes on with tendency of purchases indicator (RSF3). This change of tendency is according to the financial slack of company situated next to north frontier or Austria, as it will be analyzed later on other unit. 


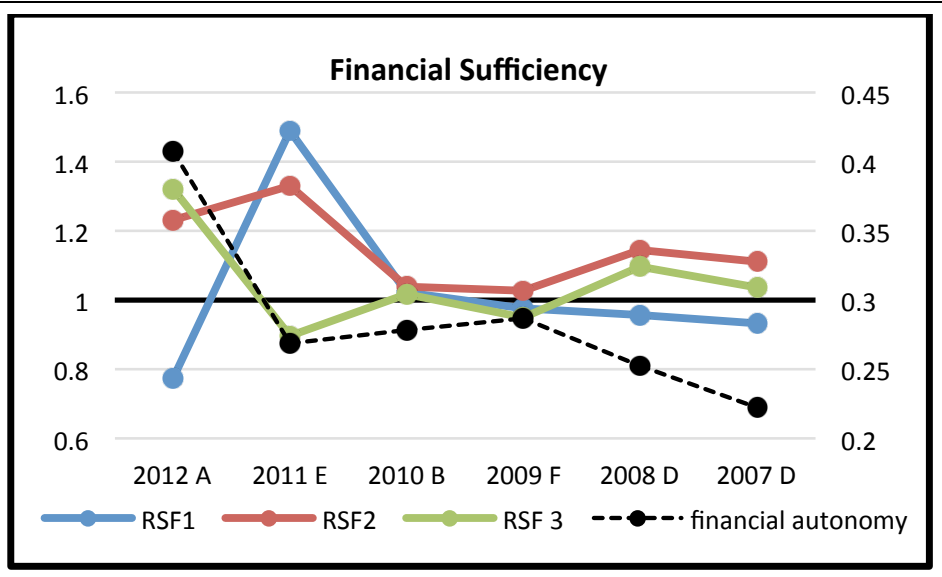

Graphic 3. Ratios of financial sufficiency.

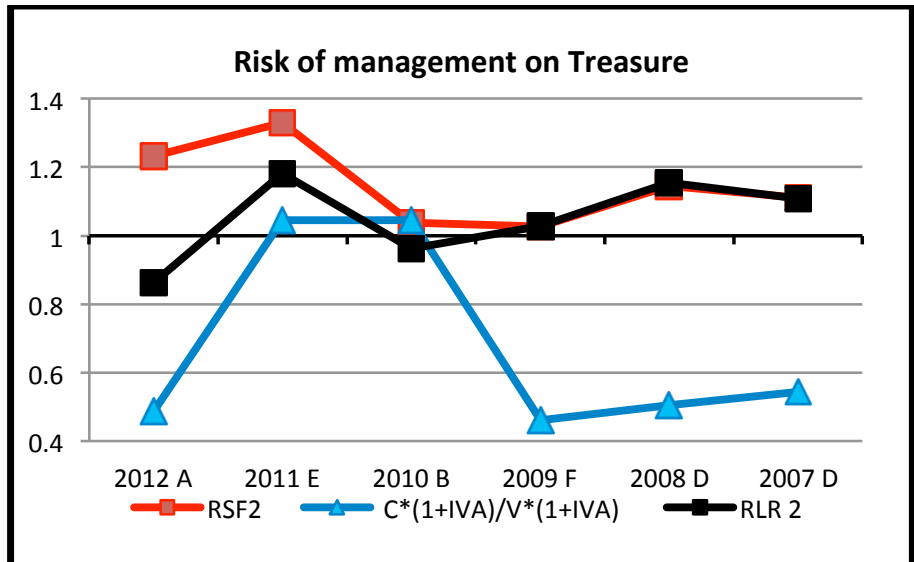

Graphic 4. Evolution of indicators of treasure area

The effect of the change commented on above paragraph is explained on through graphic four. The financial position of this Austrian company is delicate on 2009 and 2010 years. The evolution of indicator of financial sufficiency on treasury (RSF2) decreasing on 2009 year, and the ratio of liquidity result (RLR2) have the same tendency to the decreasing also, but never it still meeting the conditions of liquidity result of table 2 according its financial slack. This condition on treasure area must be fulfill on each one of kind of financial slacks.

Table 3. The angular coefficients and conditions of liquidity result.

$\begin{array}{lcccccc}\text { YEARS } & 2012 & 2011 & 2010 & 2009 & 2008 & 2007 \\ \text { AREA 1 } & \text { NO } & \text { YES } & \text { YES } & \text { N0 } & \text { N0 } & \text { N0 } \\ \text { RSF1 } & 0,775 & 1,488 & 1,021 & 0,975 & 0,958 & 0,933 \\ \text { CV/N*(1+IVA) } & 0,704 & 1,414 & 0,691 & 0,680 & 0,695 & 0,709 \\ \text { RLR 1 } & 1,114 & 1,450 & 0,978 & 0,977 & 1,035 & 1,062 \\ \text { AREA 2 } & \text { YES } & \text { YES } & \text { N0 } & \text { YES } & \text { YES } & \text { YES } \\ \text { RSF2 } & 1,232 & 1,330 & 1,039 & 1,027 & 1,144 & 1,111 \\ \text { C* }^{*}(1+\text { IVA)/N*(1+IVA) } & 0,489 & 1,044 & 1,044 & 0,461 & 0,506 & 0,545 \\ \text { RLR 2 } & 0,864 & 1,181 & 0,962 & 1,029 & 1,154 & 1,108 \\ \text { AREA 3 } & \text { YES } & \text { NO } & \text { YES } & \text { N0 } & \text { YES } & \text { YES } \\ \text { RSF 3 } & 1,321 & 0,896 & 1,018 & 0,949 & 1,096 & 1,036 \\ \text { C*(1+IVA)/CV } & 0,694 & 0,738 & 0,752 & 0,678 & 0,729 & 0,768 \\ \text { RLR 3 } & 0,775 & 0,817 & 0,983 & 1,053 & 1,115 & 1,043\end{array}$

The evolution of risk of management is measured by criteria of condition of liquidity results. This condition ceases on year 2010, according the kind of positive financial slack and the 
company improves its position on the year 2012. On years 2010 and 2011, the results of management have several problem because the purchases is higher than sales, and so this position is financing by other areas. Thereby, the area of sales on two years fulfills the conditions of RLR1, and the financial external supports this financial position according to the movement of financial autonomy on graphic 3. The decision adopted on year 2010 is relevant to continued management of company and the evolution of indicators are on table 3.

\section{Transverse analysis.}

\section{GENERAL ANALYSIS}

To evaluate the annual evolution of Austrian sector of sawmilling and planning of wood in the AMRCh methodology is on graphic 5, and the table 4 has times on which companies present a kind of financial slack each year. The graphic 5 shows the evolution of average of ratio of financial autonomy (AVFA) for all sector companies and for kind of financial slack. Its increase between years 2005 and 2007 have relation with the increases and decrease of negative (AVFANFS) and positive (AVAFPFS) financial slacks, respectively. Those two kinds of tendencies proves the trust of financial market on wood sector. Nevertheless, on year 2008 there is an inconsistency between behavior of AVFA and the variation of FSi, because a decreasing of FSP have an opposite movement on AVFANFS. It needs remember that ratio AVFA measure the relation between the Equity (numerator) and Liabilities (denominator), so its increasing have to be accord with an increasing of negative financial slack and, consequently, this indicator will decrease when the positive financial slack have an increase. So that, there are not any relations among AVFA values and the variations of Financial Slacks from 2008 up to the end of period.

Graphic 5.Evolution of financial slack and ratio of financial autonomy.

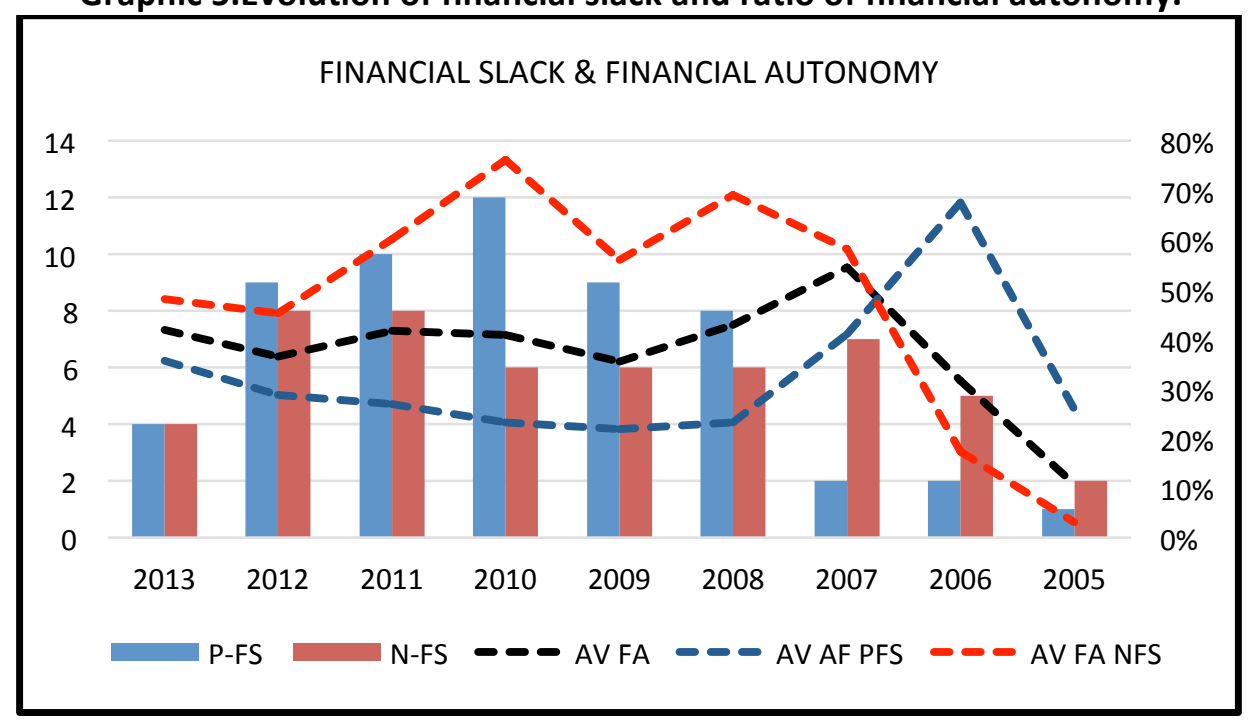

Table 4. Numbers of kinds of financial slacks.

\begin{tabular}{lcccccccccc}
0 & $\mathbf{2 0 1 3}$ & $\mathbf{2 0 1 2}$ & $\mathbf{2 0 1 1}$ & $\mathbf{2 0 1 0}$ & $\mathbf{2 0 0 9}$ & $\mathbf{2 0 0 8}$ & $\mathbf{2 0 0 7}$ & $\mathbf{2 0 0 6}$ & $\mathbf{2 0 0 5}$ & SUMAS \\
$\mathrm{A}$ & 0 & 1 & 0 & 0 & 0 & 0 & 0 & 0 & 0 & 1 \\
$\mathrm{~B}$ & 1 & 5 & 6 & 8 & 6 & 3 & 0 & 0 & 0 & 29 \\
$\mathrm{C}$ & 3 & 3 & 4 & 4 & 3 & 5 & 2 & 2 & 1 & 27 \\
$\mathrm{D}$ & 0 & 0 & 0 & 0 & 0 & 2 & 2 & 2 & 0 & 6 \\
$\mathrm{E}$ & 0 & 0 & 1 & 0 & 0 & 0 & 0 & 0 & 0 & 1 \\
$\mathrm{~F}$ & 4 & 8 & 7 & 6 & 6 & 4 & 5 & 3 & 2 & 45 \\
TOTAL & 8 & 17 & 18 & 18 & 15 & 14 & 9 & 7 & 3 & 109 \\
\hline
\end{tabular}




\begin{tabular}{lcccccccccc|c|} 
P-FS & 4 & 9 & 10 & 12 & 9 & 8 & 2 & 2 & 1 & 57 \\
N-FS & 4 & 8 & 8 & 6 & 6 & 6 & 7 & 5 & 2 & 52 \\
\cline { 2 - 13 } TOTAL & 8 & 17 & 18 & 18 & 15 & 14 & 9 & 7 & 3 & 109 \\
\hline \hline
\end{tabular}

The table 4 present the kinds of financial slacks of period and the test of Chi2 (0.4994157) indicate that the null hypothesis do not fulfilled at a level of significance of the 0.05 and there are relations among years and the financial slacks. In this relation take weigh the kinds of financial slack B, C and F.

A transversal analysis is indicating there is an increasing of companies on year 2008. This hard variation require an explication, which is not in this manuscript and it is a future line of research. However, this increase is shared between two kinds of financial slacks, and it will be studied on next paragraph. Nevertheless, the increasing of B and F financial slack show what has been the strategy of penetration on this sector. The $\mathrm{C}$ kind is present in wood sector from beginning. The $\mathrm{B}$ financial slack give more liquidity to suppliers. The F financial slack is present from beginning also and give more deferment to settle debts to clients. However, the equitable difference between positive and negative financial slacks allows suspect there is an issue for explain it, the effect frontier, which will explain in other unit of this manuscript.

\section{Transverse Analysis for management areas.}

The penetration strategies named on above paragraph needs an explanation of its effect by study of conditions of financial sufficiency and liquidity result. The table 6 take an account the time of the conditions of financial sufficiency are fulfill for management area and financial slack (FSi) and this result are on the last column. They show as the treasure area (AREA 2) have a high level of accomplishment of radial conditions at same time. Moreover, the purchases areas (AREA 3) fulfils the conditions of financial sufficiency and liquidity result higher than the sales area (AREA 1). That to say, the management results are more adjust on purchases area than sales area.

Those results indicate that the financial condition on sector allow continued the activity of company and clients portfolio condition the continued management of the activity, because the financial slack $\mathrm{F}$ has a hard weigh on the kind of sector management, according to results of table 4 and 5. On this last table, how it has been said in this paragraph, the AREA 2 presents the highest level of accomplishment to angular conditions, but among financial slacks on this area, the F kind have a high level of them in treasure area another time. This uses justify the study of frontier effect on Austrian wood sector.

A transversal analysis of results of table 5 justify the previous conclusion obtained from table 4. On bottom of table 5 there is a comparison of result between two tables. The times of conditions of sufficiency and liquidity (S\&L) are fulfilled are compare the total of kind of financial slacks from table 4. The result shows how there is a mistake on 2009 year when the value of this compilations changes and achieves a value lower than one. That to say, there are less accomplishment of angular conditions than financial slack or caseload of companies not get the financial position on short time to be adjusted to their management results. Consequently, the financial crisis is present on 2009 year and go on to the end of period, according it has been analyzed above. 
Table 6. The radial conditions for management area and financial slack

\begin{tabular}{|c|c|c|c|c|c|c|c|c|c|c|c|c|}
\hline & FSi & 2013 & 2012 & 2011 & 2010 & 2009 & 2008 & 2007 & 2006 & 2005 & SUM & FS \\
\hline AREA 1 & $\mathrm{C}$ & 0 & 1 & 1 & 2 & 0 & 2 & 1 & 1 & 0 & 8 & $\mathbf{P}$ \\
\hline AREA 1 & $\mathrm{~F}$ & 0 & 1 & 1 & 1 & 1 & 1 & 1 & 0 & 0 & 6 & $\mathbf{N}$ \\
\hline $\begin{array}{l}\text { Sales } \\
\text { area }\end{array}$ & & 0 & 2 & 2 & 3 & 1 & 3 & 2 & 1 & 0 & 14 & \\
\hline AREA 2 & $\mathrm{~A}$ & 0 & 1 & 0 & 0 & 0 & 0 & 0 & 0 & 0 & 1 & $\mathbf{P}$ \\
\hline AREA 2 & $\mathrm{C}$ & 1 & 0 & 0 & 1 & 2 & 4 & 3 & 2 & 0 & 13 & $\mathbf{P}$ \\
\hline AREA 2 & $\mathrm{D}$ & 0 & 0 & 0 & 0 & 0 & 1 & 1 & 1 & 0 & 3 & $\mathbf{N}$ \\
\hline AREA 2 & $\mathrm{~F}$ & 4 & 8 & 7 & 6 & 5 & 4 & 5 & 3 & 1 & 43 & $\mathbf{N}$ \\
\hline $\begin{array}{l}\text { Treasure } \\
\text { area }\end{array}$ & & 5 & 9 & 7 & 7 & 7 & 5 & 8 & 6 & 1 & 60 & \\
\hline AREA 3 & $\mathrm{~A}$ & 0 & 1 & 0 & 0 & 0 & 0 & 0 & 0 & 0 & 1 & $\mathbf{P}$ \\
\hline AREA 3 & B & 1 & 2 & 2 & 3 & 3 & 0 & 0 & 0 & 0 & 11 & $\mathbf{P}$ \\
\hline AREA 3 & $\mathrm{C}$ & 1 & 1 & 0 & 2 & 1 & 3 & 1 & 1 & 0 & 10 & $\mathbf{P}$ \\
\hline AREA 3 & $\mathrm{D}$ & 0 & 0 & 0 & 0 & 0 & 1 & 1 & 1 & 0 & 3 & $\mathbf{N}$ \\
\hline \multirow[t]{3}{*}{$\begin{array}{l}\text { Purchases } \\
\text { area }\end{array}$} & & 2 & 4 & 2 & 5 & 4 & 4 & 2 & 2 & 0 & 25 & \\
\hline & & 7 & 15 & 11 & 15 & 12 & 16 & 13 & 9 & 1 & 99 & \\
\hline & & 2013 & 2012 & 2011 & 2010 & 2009 & 2008 & 2007 & 2006 & 2005 & \multicolumn{2}{|l|}{ SUM } \\
\hline S \& L (a) & & 7 & 15 & 11 & 15 & 12 & 16 & 13 & 9 & 1 & \multicolumn{2}{|l|}{99} \\
\hline TOTAL (b) & & 8 & 17 & 18 & 18 & 15 & 14 & 9 & 7 & 3 & \multicolumn{2}{|l|}{109} \\
\hline$(a) \div(b)$ & & 0,875 & 0,882 & 0,611 & 0,833 & 0,8 & 1,143 & 1,444 & 1,286 & 0,333 & & \\
\hline
\end{tabular}

\section{Analysis by companies by frontier effect.}

The analysis of wood sector is divided on two sides, companies situated on north and south of Austria. Their approach to frontiers countries with different Gross Domestic Product has effects on management strategies of companies. The result of observations on this study is on table 7, where the name of companies is under acronyms and all of they are the database on this manuscript. The annual financial statements has been obtained from database Orbis, but the analysis is only to companies on table 7 because not all of 25 selected company firstly have a valid accounting information for to be evaluated.

The companies with a positive financial slack and next to northern frontier have positive financial slacks and the company localized below this criterion with other kind of financial slack change its strategy. These examples are on table 7 marked with an F and it is the AEGE company. The companies situated on southern frontier have negative financial slacks and their changes from positive to negative financial slacks can be seed on USTR and SAEG companies at the end of period. Moreover, there are exceptions on this criterion and they are marked on table 7 with an asterisk symbol. But despite this, the main difference is the required liquidity on negative financial slacks, when companies are situated on southern frontier and this issue is more sensitive on company situate on the northern of Austria at the end of period, because the $\mathrm{C}$ and $\mathrm{F}$ financial slack are more present than other kind of financial slack. These differences have their consequences on the study of angular conditions. 


\begin{tabular}{|c|c|c|c|c|c|c|c|c|c|c|c|c|c|c|c|c|c|c|c|}
\hline $\begin{array}{l}\text { Table } \\
\text { companie }\end{array}$ & es $7:$ & & & & & ears & & & & & & & inar & ncial & I sla & & & & \\
\hline $\begin{array}{l}\text { ACRON } \\
\text { YM }\end{array}$ & REGION & $\begin{array}{l}20 \\
13\end{array}$ & $\begin{array}{l}20 \\
12\end{array}$ & $\begin{array}{l}20 \\
11\end{array}$ & $\begin{array}{l}20 \\
10\end{array}$ & $\begin{array}{l}20 \\
09\end{array}$ & $\begin{array}{l}20 \\
08\end{array}$ & $\begin{array}{l}20 \\
07\end{array}$ & $\begin{array}{l}20 \\
06\end{array}$ & $\begin{array}{l}20 \\
05\end{array}$ & C. & L A & $B$ & C & & $\mathrm{E}$ & $\mathrm{F}$ & & \\
\hline A EN & BRAND & B & B & B & B & B & C & 0 & C & 0 & $\begin{array}{l}\text { (c } \\
z)\end{array}$ & $\mathrm{NO}$ & 5 & 2 & 0 & 0 & 0 & 7 & \\
\hline HOLZ & $\begin{array}{c}\text { RANDEGG } \\
\text { (NOE) }\end{array}$ & 0 & B & B & B & B & B & 0 & 0 & 0 & $\begin{array}{l}\text { (c } \\
\mathrm{z})\end{array}$ & $\mathrm{NO}$ & 5 & 0 & 0 & 0 & 0 & 5 & \\
\hline AEGE & $\begin{array}{l}\text { STEYRERMUEH } \\
\text { L }\end{array}$ & C & $\mathrm{F}$ & C & C & 0 & C & C & $F$ & $\mathrm{~F}$ & $\begin{array}{l}\text { (d } \\
e)\end{array}$ & $\mathrm{NO}$ & 0 & 5 & 0 & 0 & 3 & 8 & (F) \\
\hline ELNH & $\begin{array}{l}\text { FRANKENMARK } \\
T\end{array}$ & $\mathrm{~F}$ & C & B & B & B & C & C & 0 & 0 & $\begin{array}{l}\text { (d } \\
e)\end{array}$ & $\mathrm{NO}$ & 3 & 3 & 0 & 0 & 1 & 7 & \\
\hline BAU & IMST & C & C & B & B & B & 0 & 0 & 0 & 0 & $\begin{array}{l}\text { (c } \\
\mathrm{h})\end{array}$ & $\mathrm{No}$ & 3 & 2 & 0 & 0 & 0 & 5 & \\
\hline ETTE & VILS & 0 & B & $B$ & B & B & B & 0 & 0 & 0 & $\begin{array}{l}\text { (c } \\
\text { h) }\end{array}$ & $\mathrm{NO}$ & 5 & 0 & 0 & 0 & 0 & 5 & \\
\hline ERW & $\begin{array}{l}\text { GOLDEGG IM } \\
\text { PONGAU }\end{array}$ & C & C & C & C & C & C & 0 & 0 & 0 & $\begin{array}{l}\text { (d } \\
e)\end{array}$ & $\mathrm{No}$ & 0 & 6 & 0 & 0 & 0 & 6 & \\
\hline $\mathrm{ACHE}$ & HERMAGOR & 0 & B & C & B & 0 & 0 & 0 & 0 & 0 & (it) & $S 0$ & 2 & 1 & 0 & 0 & 0 & 3 & $\left({ }^{*}\right)$ \\
\hline HP E & FRAUENTAL & 0 & 0 & C & C & C & C & 0 & 0 & 0 & $\begin{array}{l}\text { (s } \\
k)\end{array}$ & $\mathrm{No}$ & 0 & 4 & 0 & 0 & 0 & 4 & \\
\hline NDER & FUEGEN & $\mathrm{F}$ & $\mathrm{F}$ & $\mathrm{F}$ & $\mathrm{F}$ & $\mathrm{F}$ & D & D & 0 & 0 & $\begin{array}{l}(d \\
e)\end{array}$ & $\mathrm{NO}$ & 0 & 0 & 2 & 0 & 5 & 7 & $\left({ }^{*}\right)$ \\
\hline EIFE & IMST & 0 & $\mathrm{~F}$ & $\mathrm{~F}$ & $\mathrm{~F}$ & $\mathrm{~F}$ & $\mathrm{~F}$ & $\mathrm{~F}$ & $\mathrm{~F}$ & 0 & $\begin{array}{l}\text { (c } \\
\text { h) }\end{array}$ & $\mathrm{NO}$ & 0 & 0 & 0 & 0 & 7 & 7 & $\left(^{*}\right)$ \\
\hline OLZ & LEOBEN & $\mathrm{F}$ & $\mathrm{F}$ & $\mathrm{F}$ & $\mathrm{F}$ & $\mathrm{F}$ & $\mathrm{F}$ & $\mathrm{F}$ & 0 & 0 & $\stackrel{(s i}{)}$ & S 0 & 0 & 0 & 0 & 0 & 7 & 7 & \\
\hline HANN & ZELTWEG & 0 & $\mathrm{~F}$ & $\mathrm{~F}$ & $\mathrm{~F}$ & 0 & 0 & 0 & 0 & 0 & (si & $S 0$ & 0 & 0 & 0 & 0 & 3 & 3 & \\
\hline N OF & $\begin{array}{l}\text { WOLFSBERG } \\
\text { (KTN.) }\end{array}$ & 0 & $\mathrm{~F}$ & $\mathrm{~F}$ & $\mathrm{~F}$ & $\mathrm{~F}$ & $\mathrm{~F}$ & $\mathrm{~F}$ & D & $\mathrm{F}$ & $\stackrel{(s i}{)}$ & S 0 & 0 & 0 & 1 & 0 & 7 & 8 & \\
\hline USTR & ADMONT & $\mathrm{F}$ & $\mathrm{F}$ & $\mathrm{F}$ & C & C & $\mathrm{C}$ & $F$ & $F$ & 0 & $\begin{array}{l}(\mathrm{si} \\
)\end{array}$ & S 0 & 0 & 3 & 0 & 0 & 5 & 8 & (F) \\
\hline RFLZ & ZELL AM MOOS & 0 & A & $E$ & B & $\mathrm{F}$ & D & D & D & 0 & $\begin{array}{l}\text { (d) } \\
\text { e) }\end{array}$ & N 1 & 1 & 0 & 3 & 1 & 1 & 7 & $\begin{array}{l}(\mathrm{F})( \\
*)\end{array}$ \\
\hline SAEG & EPPENSTEIN & 0 & $\mathrm{~F}$ & $\mathrm{~F}$ & $\mathrm{~F}$ & $\mathrm{~F}$ & $\mathrm{~F}$ & $\mathrm{~F}$ & C & C & $\begin{array}{l}(s i \\
)\end{array}$ & $\begin{array}{r}S 0 \\
0\end{array}$ & $\begin{array}{l}0 \\
2 \\
4\end{array}$ & $\begin{array}{l}2 \\
2 \\
8\end{array}$ & 0 & $\begin{array}{l}0 \\
1\end{array}$ & $\begin{array}{l}6 \\
4 \\
5\end{array}$ & $\begin{array}{c}10 \\
5\end{array}$ & $(F)$ \\
\hline
\end{tabular}

Colum C: Country more next to company. The acronym to country is according to IANA domain. Colum L: Location of Company in Austria.

Characters: $(F)$ Company with frontier effect; $\left({ }^{*}\right)$ Exception to general criteria.

The financial sufficiency on graphics 8 and 9 has a different behavior, as it was to suppose. When companies are on northern frontier, the behaviors of purchases and treasure areas are same. Nevertheless, the financial sufficiency on portfolio client is higher than of purchases, and it supposes their clients are on countries with a high Gross Domestic Product. When companies are on south frontier, next to countries with a low Gross Domestic Product, the behavior of purchases and sales area are same, and the treasure maintain the same level along of period. This uses made the conditions of financial management are relevant on continuity activity to south companies. 


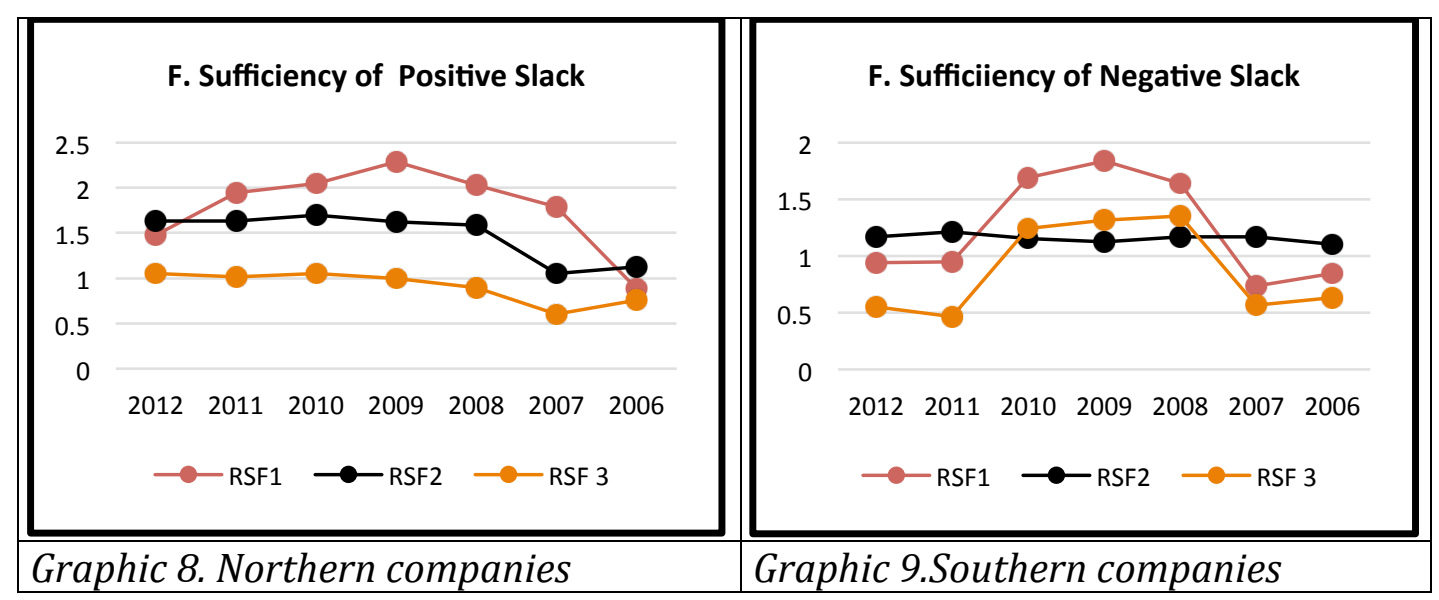

The quality of financial sufficiency can be evaluated by the conditions of the liquidity result. The evolution of management activity to north frontier companies of table 7 is represented on graphic 10 and the valuation of angular indicators are on table 8. Moreover, the graphic 11 represent the evolution of south companies and their valuation of management through angular indicator is on table 9. Nevertheless, the criteria of kind of financial slack applied for this each kind of company have been $\mathrm{B}$ and $\mathrm{C}$ for north companies and $\mathrm{F}$ for south companies.

\begin{tabular}{|c|c|c|}
\hline \multirow[t]{2}{*}{ CS/LR } & $\begin{array}{l}\text { EVALUACIÓ DE LAS AREAS } \\
\text { TO FINANCIAL SLACK (C) }\end{array}$ & $\begin{array}{l}\text { EVALUACIÓ DE LAS AREAS } \\
\text { TO FINANCIAL SLACK (F) }\end{array}$ \\
\hline & AREA 1 & AREA 1 \\
\hline SC1 & $\alpha 2 / \beta 3>1$ & $\beta 3 / \alpha 2>1$ \\
\hline \multirow[t]{2}{*}{ LR1 } & $1>\beta 2 / \alpha 3>C V / V^{*}(1+I V A)(Y E S)$ & $\beta 2 / \alpha 3<C V / N^{*}(1+I V A)($ no $)$ \\
\hline & AREA 2 & AREA 2 \\
\hline SC2 & $\beta 1 / \alpha 3>1$ & $\alpha 3 / \beta 1>1$ \\
\hline \multirow[t]{2}{*}{ LR2 } & $1>\alpha 1 / \beta 3>C^{*}(1+I V A) / V^{*}(1+I V A)(Y E S)$ & $\alpha 1 / \beta 3<C^{*}(1+I V A) / V^{*}(1+I V A)($ no $)$ \\
\hline & AREA 3 & AREA 3 \\
\hline SC3 & $\beta 2 / \alpha 1>1$ & $\alpha 1 / \beta 2>1$ \\
\hline LR3 & $\beta 1 / \alpha 2<C^{*}(1+I V A) / C V<1$ (no) & $\beta 1 / \alpha 2>C^{*}(1+I V A) / C V(Y E S)$ \\
\hline
\end{tabular}

The conditions of liquidity result are fulfill on 2005, 2006 and 2007 years on treasure area, and from 2008 to 2010 years these conditions do not fulfill on all areas. Thus, the financial autonomy decrease because companies need external financial to maintain a strategic management. On 2011, 2012 and 2013 years the management situation increases, because companies gets liquidity result on purchases areas at same time that this area get too liquidity result. On year 2013, these two conditions are fulfill on area of treasure, and it indicate the companies get financial sufficiency from its result on this area. The situation on 2013 is same that on 2005 and 2006 years, the external conditions of financial market get maintain the management activity companies, because there are not any relations between the management result and the financial sufficiency on treasure area. The financial situation of companies on 2013 year improve because the ratio of financial sufficiency increases and all management areas get financial sufficiency, this is the difference respect to 2005 and 2006 years. 


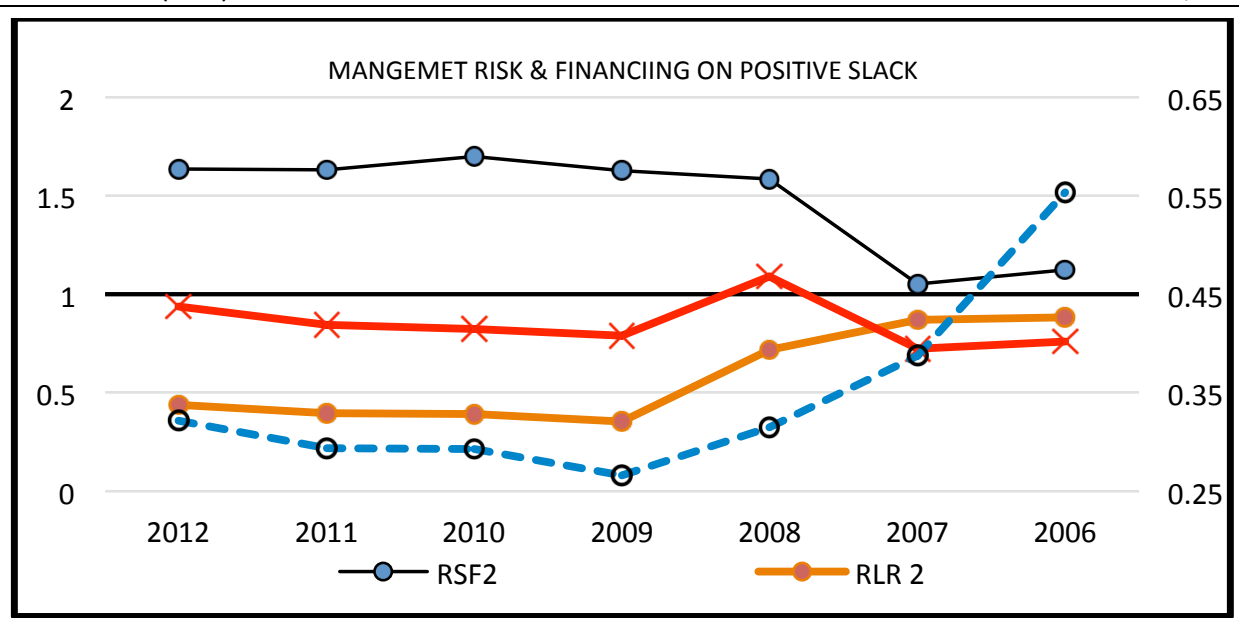

Graphic 10. The evaluation of treasure area on north companies

Table 8. The average of angular indicators of treasure area on north companies

AREA1

RSF1

CV/N*(1+IVA)

RLR 1

AREA 2

RSF2

$\mathrm{C}^{*}(1+$ IVA $) / \mathrm{V}^{*}(1+$ IVA $)$

RLR 2

AREA 3

RSF 3

$\mathrm{C}^{*}(1+$ IVA $) / \mathrm{CV}$

RLR 3

financial autonomy
2013* 2012

0
1,563

0,878

0,506

1
1,408

0,905

1,189

0

1,041

1,828

0,338
2011

$$
0
$$

2010

2009

2008 2007

2006

2005

$\left(^{*}\right)$ these years are evaluated through C Kind of financial slack.

1,951

0,804

0,401

2,044

2,291

2,031

0,792

0,943

0,921

0,380

0,373

0,586

0,407

0,659

$\begin{array}{rr}0 & 0 \\ 1,701 & 1,626\end{array}$

0,825

0,790

1,584

1,090

0,715

0,391

0,353

0

1,049

1,067

1,001

0,821

1,129

0,976

1,412

0,315
1
1,052

1,052

0,723

0,871

0

0,604

0,723

1,318

0,388
0

0,888

0,456

$0,679 \quad 0,891$

$0,761 \quad 0,821$

$0,884 \quad 3,985$

$0,758 \quad 0,280$

$2,389 \quad 3,830$

$1,312 \quad 4,747$

$0,554 \quad 0,233$
11

$1,123 \quad 1,230$

The evolution of south companies have a different behavior, and their evaluations will made by F financial slack. This kind of financial slack is the main on south companies, and both their behavior and their assessment are found in Graphic 11 and Table 9. They never achieve an optimal management on period of study, from years 2005 to 2013, because management areas do not get financial sufficiency and liquidity result. Moreover, the three indicators on treasure area have the same behavior along of period, and the variation of management result is according to variation of liquidity result on treasure area (RLR2). That is to say, the management result adjusts to financial position on area of treasure and the alternatives of decisions are limited. On others words, the company need external financial to maintain their activity in these conditions of liquidity result, and this explain the behavior of financial autonomy.

The financial autonomy increases on years 2007 and 2008, but its decreasing is constant on next years since year 2009. It justifies the high level of management risk on treasure and purchases areas, it due to that the RLR2 indicator is higher than one and an external financing to them supports the financial sufficiency on these areas. By the contrary, the sales area has the best behavior of them, how it was studied on graphic number 9, because this one ever fulfills the conditions of liquidity result and also the ratio of financial sufficiency (RSF1) is next to one on year 2001 and 2012. Nevertheless, the management result improves on year 2012 as well as the liquidity result on all areas, so that the financial autonomy increases on year 2013 because the level of trust on shareholders increases too. It is need remember that $F$ kind of 
financial slack has the large perimetral distance on treasure areas (PD2) and it represents the big distance to settle the commitment of debtors. Under these conditions of management, companies manage their activities giving credit to clients and the increase of financial autonomy proves the trust of shareholders on the continued activity of their companies.

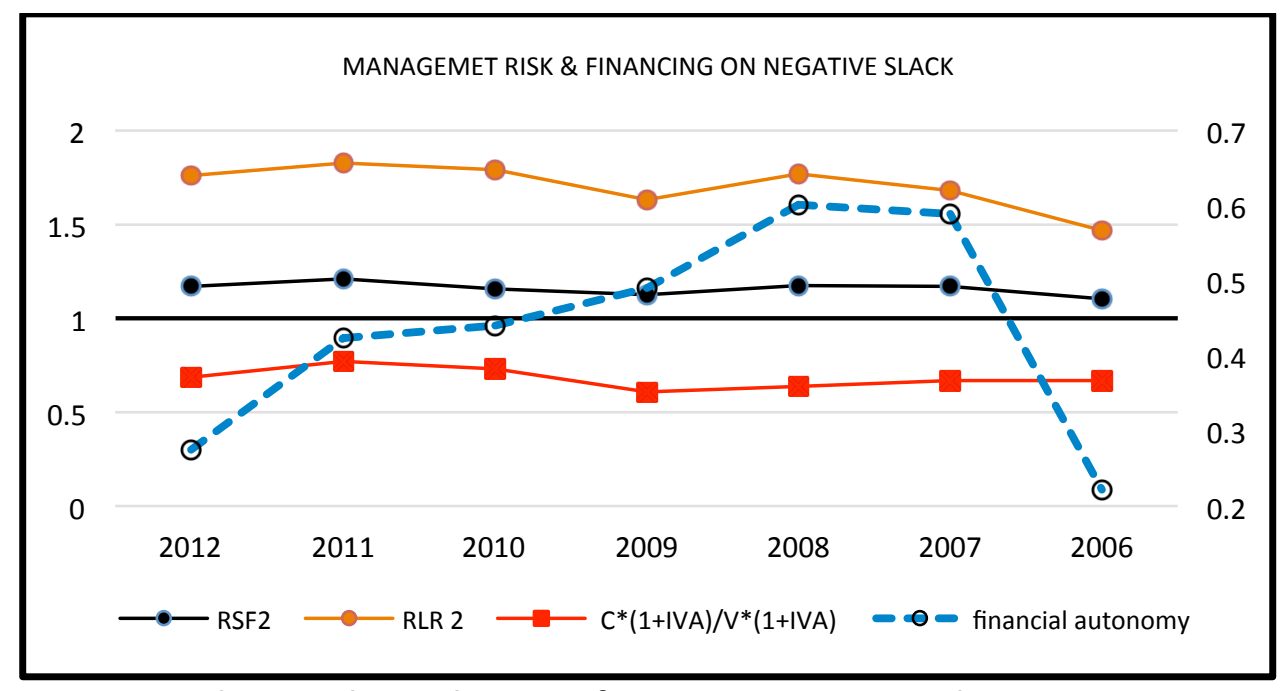

Graphic 11. The evaluation of treasure area on south companies

Table 9. The average of angular indicators of treasure area on south companies

$\begin{array}{lrrrrrrrrr}\text { FINANCIAL SALCK F } & 2013 & 2012 & 2011 & 2010 & 2009 & 2008 & 2007 & 2006 & 2005 \\ \text { AREA 1 } & 0 & 0 & 0 & 1 & 1 & 1 & 0 & 0 & 1 \\ \text { RSF1 } & 0,481 & 0,941 & 0,946 & 1,690 & 1,837 & 1,637 & 0,732 & 0,849 & 1,697 \\ \text { CV/N*(1+IVA) } & 0,710 & 0,723 & 0,751 & 0,623 & 0,565 & 0,565 & 0,537 & 0,569 & 0,704 \\ \text { RLR 1 } & 0,769 & 0,855 & 0,877 & 0,800 & 0,775 & 0,822 & 0,851 & 0,816 & 0,725 \\ \text { AREA 2 } & 0 & 0 & 0 & 0 & 0 & 0 & 0 & 0 & 0 \\ \text { RSF2 } & 1,096 & 1,170 & 1,211 & 1,156 & 1,125 & 1,173 & 1,169 & 1,104 & 1,130 \\ \text { C*}^{*}(1+\text { IVA)/N*(1+IVA) } & 0,633 & 0,687 & 0,770 & 0,731 & 0,608 & 0,639 & 0,667 & 0,670 & 0,781 \\ \text { RLR 2 } & 1,422 & 1,762 & 1,828 & 1,791 & 1,631 & 1,768 & 1,682 & 1,468 & 1,014 \\ \text { AREA 3 } & 0 & 0 & 0 & 0 & 0 & 0 & 0 & 0 & 0 \\ \text { RSF 3 } & 0,425 & 0,550 & 0,465 & 1,245 & 1,317 & 1,353 & 0,564 & 0,630 & 0,586 \\ \text { C }^{*}(1+\text { IVA)/CV } & 0,890 & 0,962 & 1,216 & 1,367 & 1,602 & 1,830 & 2,281 & 2,093 & 0,931 \\ \text { RLR 3 } & 1,934 & 2,181 & 2,226 & 2,302 & 2,171 & 2,279 & 2,176 & 1,923 & 1,390 \\ \text { financial autonomy } & 0,554 & 0,319 & 0,451 & 0,468 & 0,523 & 0,630 & 0,614 & 0,258 & 0,160\end{array}$

To contrast the obtained result by the AMRCh methodology with information from financial statements, the evolution of elasticity of treasure respect the variation of financial autonomy is on graphic 12 explain the differences on two kind of companies. 


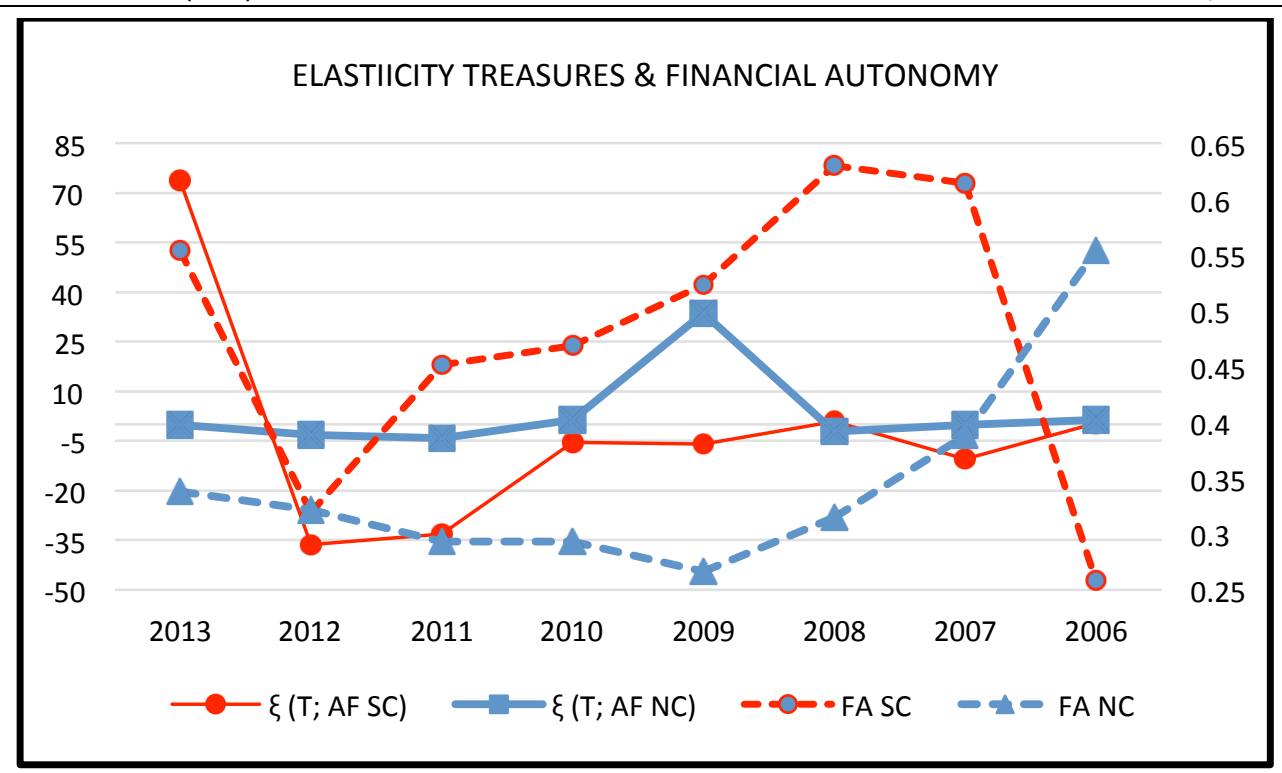

Graphic 12. The evaluation of treasure companies

Table 10. Valuation of the north and south companies.

$\begin{array}{lrrrrrrrr}\text { negative financial slacks } & 2013 & 2012 & 2011 & 2010 & 2009 & 2008 & 2007 & 2006 \\ \text { financial autonomy } & 0,554 & 0,319 & 0,451 & 0,468 & 0,523 & 0,630 & 0,614 & 0,258 \\ \begin{array}{l}\text { § (T; AF SC) } \\ \text { positive financal slacks }\end{array} & 73,58 & -36,3 & -33,2 & -5,45 & -5,87 & 0,96 & -10,49 & 0,33 \\ \text { financial autonomy } & & & & & & & & \\ \xi(T ; \text { AF NC) } & 0,338 & 0,321 & 0,293 & 0,293 & 0,266 & 0,315 & 0,388 & 0,554 \\ & -0,152 & -3,107 & -4,168 & 1,327 & 33,52 & -2,18 & -0,105 & 1,442\end{array}$

The elasticity of treasure and financial autonomy justifies the evolution of treasury respect to the behavior of financial structure of liability. The behaviors of north and south companies' elasticity are different. They have dashed line on Graphic 12 and their values are on secondary $y$-axis and on table 10. Since 2009 the south companies only have financial sufficiency on treasure area and their annual elasticities have too a hard movement. Therefore, the north elasticity has values higher than one on years 2007 and 2008, when company has not financial sufficiency on all areas. This relation justify the application of AMRCh methodology because it can explain better the management of company. The angular indicators are normalized, independent and objective and the quality of financial position takes as reference a gap between the ratio of liquidity result and the result of management on each area. Finally, this methodology can explain the multidirectional effects of making decisions.

\section{CONCLUSION}

This manuscript has begun analyzing Austrian companies by accounting methodology of radar chart. The first analysis carry out us to differ two kind of management, and it has detected a frontier effect. The classification of companies in clusters makes analysis more consistent whether traditional techniques are applied or not, but the new methodology lets to do a singular analysis to each management area which cannot be done otherwise. All management wishes to know the effect of your decisions and this methodology increases his or her perceptions because it shows the multidirectional effects of making decision on each areas represented on a radar chart. Moreover, the new methodology increases the analytic capacity of methodology traditional and justify the selection of variables to explain the behavior of companies, because the radial indicator are normalized, objective and independent and the AMRCh can be applied ever. That is to say, for an analyst is relevant the kind of variables to must apply on a study and he or she knows that selected variables for an analysis maybe they not will be applied along of period of study. Well this methodology can guide the research but 
it cannot replace your knowledge about the best technique of analysis to be applied in a study. Finally, this study only seeks to explain the explanatory power of the AMRCh to improve our decisions whether in times of crisis or not. The new line of research well be the prospective and retrospective power of radial variables.

\section{References}

Brusca Alijarde, I., \& Montesinos Julve, V. (2014). Accrual Financial Reporting in the Public Sector: Is it a Reality? Innovar, 24(54), 107-120.

CNMV. Comisión Nacional Del Mercado de Valores, 2013. Guide for the preparation of management reports of listed companies. https://www.cnmv.es/DocPortal/Publicaciones/Grupo/gestion_EN_Weben.pdf.

Erliza, A, Zakaria, R., Sutopo, W., Widiyanto, A. and Supriyanto, E. (2014). Formulation Strategy for Promoting Investment Of Technopolis: A Case Study. The International Multi-Conference of Engineers and Computer Scientists. Vol II, 12 - 14. http://www.iaeng.org/publication/IMECS2014/

Kattel, R., Drechsler, W \& Reinert, E.S. (2014). The New Public Management Then and Now: Lessons from the Transition in Central and Eastern Europe. Working Papers in Technology Governance and Economic Dynamics no. 57.

Kuipers, B.S., Higgs, M.J., Kickert, W.J.M., Tummers, L.G., Grandia, J., Van der Voet, J. (2014). The management of change in public organizations: A literature review. Public Administration.

IASB. International Accounting Standards Board. IFRS Practice Statement Management Commentary. A framework for presentation (2010). http://www.ifrs.org/Current-Projects/IASB-Projects/Management-Commentary/ IFRS- PracticeStatement/Pages/IFRS-Practice-Statement.aspx.

IOSCO. Report of the Technical Committee of the International Organization of Securities Commissions (2003). General Principles Regarding Disclosure of Management's Discussion and Analysis of Financial Condition and Results of Operations. https://www.iosco.org/library/pubdocs/pdf/IOSCOPD141.pdf.

Prewitt, J.E. \& Weil, R. (2014). Organizational Opportunities Endemic in Crisis Leadership. Journal of Management Policy and Practice vol. 15(2).

SEC. Securities and Exchange Commission (2010). 17 CFR PARTS 211, 231 and 241. Release Nos. 33-9144; 34-62934; FR83. Commission Guidance on Presentation of Liquidity and Capital Resources Disclosures in Management's Discussion and Analysis. http://www.sec.gov/rules/interp/2010/33-9144.pdf.

Van Durme, Th., Macq, J., Anthierens, S., Symons, L., Schmitz, O., Paulus, D., Van den Heede, K. and Remmen, R. (2014). Stakeholders' perception on the organization of chronic care: a SWOT analysis to draft avenues for health care reforms. BMC Health Services Research 2014, 14:179. http://www. biomedcentral.com/1472-6963/14/179 